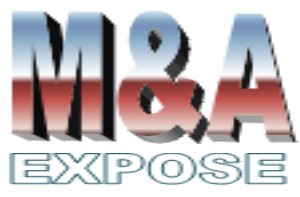

http://jurnal.usahid.ac.id/index .php/accounting
Universitas Muhammadiyah Makassar 1atika.unismuh@gmail.com

\section{Dampak Locus Of Control, Sikap Keuangan, Pendapatan, dan Religiusitas terhadap Perilaku Keuangan}

\author{
Atika Ahmad $^{1}$
}

\section{Abstrak}

Anggota organisasi kemasyarakatan berbasis agama memiliki pandangan yang khas mengenai faktor spiritual yang berdampak pada perilaku kesehariannya. Penelitian ini bertujuan menganalisis perilaku keuangan anggota organisasi Muhammadiyah, Kabupaten Bantaeng, Sulawesi Selatan ditinjau berdasarkan prediktor locus of control, sikap keuangan, pendapatan dan religiusitas. Teknik analisis menggunakan regresi linier berganda, dengan sampel jenuh. Hasil penelitian menyimpulkan bahwa variabel locus of control, sikap keuangan, pendapatan dan religiusitas baik secara parsial maupun simultan berpengaruh signifikan terhadap perilaku keuangan anggota Muhammadiyah. Variabel yang paling dominan dalam mempengaruhi perilaku keuangan adalah pendapatan.

Kata kunci : locus of control, sikap keuangan, pendapatan, religiusitas, perilaku keuangan.

\section{Abstract}

Members of religious-based community organizations have unique views on spiritual factors that affect their daily behavior. This study aims to analyze the financial behavior of members of the Muhammadiyah organization, Bantaeng Regency, South Sulawesi, based on predictors of locus of control, financial attitudes, income and religiosity. The analysis technique uses multiple linear regression, with saturated samples. The results of the study concluded that the locus of control variables, financial attitudes, income and religiosity both partially and simultaneously significantly influence the financial behavior of Muhammadiyah members. The most dominant variable in influencing financial behavior is income.

Keywords: locus of control, financial attitude, income, religiosity, financial behavior. 


\section{PENDAHULUAN}

Rendahnya tingkat pemahaman pengelolaan keuangan menyebabkan banyak masyarakat yang mengalami masalah keuangan, baik akibat akibat penurunan kondisi perekonomian maupun karena semakin pesatnya laju konsumerisme (Enrico, Aron, \& Oktavia, 2013; Sitepu, 2017). Perilaku keuangan masyarakat Indonesia yang cenderung konsumtif kemudian menimbulkan berbagai perilaku keuangan yang tidak bertanggung jawab seperti kurangnya kegiatan menabung, investasi, perencanaan dana darurat dan penganggaran dana untuk masa depan. Fenomena ini nampak jelas dari hasil studi Otoritas Jasa Keuangan, yang mendapati literasi keuangan masyarakat masih pada level menengah, yaitu 75,69 persen dan hanya 21,84 persen yang betul-betul mengetahui beragam produk dan jasa keuangan. Fenomena empiris ini menjadi salah satu landasan penelitian ini.

Di jajaran negara-negara Asia Tenggara pun, Indonesia menempati urutan terbawah dalam hal total nominal tabungan dan kebiasaan menabung. Hal ini disebabkan banyaknya masyarakat yang tidak berinvestasi karena belum memiliki pengetahuan keuangan. Itulah sebabnya perilaku keuangan menjadi isu yang sangat menarik dikaji dewasa ini. Perilaku keuangan sangat erat kaitannya dengan perilaku konsumsi individu atau masyarakat. Masyarakat yang memiliki pendapatan yang besar belum tentu dapat mengatur pengeluaran keuangannya dengan baik. Perilaku keuangan yang kurang bertanggungjawab cenderung mendorong individu berpikir jangka pendek dan identik dengan belanja impulsif (Amar, Syariati, \& Rahim, 2019). Fenomena ini menyebabkan individu dengan pendapatan yang cukup besar pun masih mengalami masalah finansial. Secara umum, apabila seseorang bertambah pendapatannya, maka pengeluarannya akan ikut bertambah, bahkan terkadang melebihi penambahan pendapatan (Meghir \& Pistaferri, 2011). Hal tersebut disebabkan oleh perubahan gaya hidup. Seseorang dengan gaya hidup mewah akan memiliki kebutuhan yang banyak, dan sebaliknya dengan gaya hidup yang tidak mewah maka seseorang akan memiliki kebutuhan yang lebih terbatas.

Penelitian ini bertujuan menganalisis perilaku keuangan pengurus organisasi keagamaan Muhammadiyah (Parmitasari, Alwi, \& S., 2018). Indonesia sebagai negara dengan pemeluk agama Islam terbesar di dunia memiliki keseharian yang tidak terlepas dari faktor agama (Suhartini \& Anisa, 2017). Sumbangsih teoretis dan empiris khususnya pada organisasi keagamaan Muhammadiyah, walaupun masih pada tahap lokal, akan menjadi sumbangsih penelitian yang penting bagi keilmuan perilaku individu.

\section{TINJAUAN PUSTAKA}

Terdapat beberapa definisi perilaku keuangan, antara lain sebagai studi yang mempelajari bagaimana fenomena psikologi mempengaruhi tingkah laku keuangan individu yaitu menyatakan tingkat laku para praktisi (Shefrin \& Statman, 2000). Terdapat definisi yang lain yaitu perilaku keuangan sebagai apa saja yang relevan terkait manajemen uang individu (Xiao, 2008). Pendapat lain mendefinisikan perilaku keuangan mengenai kajian bagaimana manusia secara aktual berperilaku dalam sebuah penentuan keuangan, khususnya bagaimana proses pengambilan keputusan terkait hal tersebut (Ricciardi, 2008). Dari beragam definisi di atas, maka penelitian ini menelaah perilaku keuangan dari sisi bagaimana pengurus Muhammadiyah membuat beragam keputusan keuangan. 
Konsep locus of control pertama kali dikemukakan oleh Rotter, seorang ahli teori pembelajaran sosial. Locus of control adalah cara pandang seseorang terhadap sesuatu peristiwa apakah dia merasa dapat atau tidak mengendalikan perilaku yang terjadi padanya. Terdapat beragam cara mengukur locus of control di antaranya adalah dimensi pengukuran di tempat kerja (Spector, 1988), ataupun di dunia kesehatan (Wallston, Wallston, \& DeVellis, 1978). Berikut adalah pengembangannya pada berbagai sektor, hingga penerapan di dunia keuangan (Cobb-Clark, Kassenboehmer, \& Sinning, 2016). Dalam penelitian ini, locus of control diduga merupakan prediktor terhadap perilaku keuangan pengurus Muhammadiyah. Penelitian sebelumnya mendukung secara signifikan hubungan kedua variabel tersebut (Britt, Cumbie, \& Bell, 2013; Ida \& Dwinta, 2010; Perry \& Morris, 2005). Perubahan pemicu dari sisi internal maupun eksternal akan memicu perubahan perilaku keuangan yang semakin baik. Berdasarkan hal tersebut, penelitian ini merumuskan hipotesis :

$\mathrm{H} 1$ : Locus of Control berpengaruh positif terhadap perilaku keuangan pengurus Muhammadiyah.

Sikap adalah pernyataan yang evaluatif baik menyenangkan maupun tidak menyenangkan terhadap objek, individu, dan peristiwa (Robbins \& Judge, 2009). Sikap terhadap uang merupakan pendahuluan terciptanya perilaku terkait uang, dan merupakan kecenderungan untuk berperilaku atau tidak berperilaku terkait sesuatu (Falahati, 2011). Definisi lain menjelaskan sikap keuangan sebagai keadaan pikiran, opini, maupun pendapat seseorang terkait aspek keuangan (Ameliawati \& Setiyani, 2018). Keseluruhan pendapat tersebut mendukung signifikansi hubungan antara sikap keuangan dengan perilaku keuangan (Ameliawati \& Setiyani, 2018; Falahati, 2011; Lai, 2010; Yap, Komalasari, \& Hadiansah, 2018). Berdasarkan hal tersebut, penelitian ini merumuskan hipotesis :

H2 : Sikap keuangan berpengaruh positif terhadap perilaku keuangan pengurus Muhammadiyah.

Pendapatan dapat diartikan sebagai sebuah hasil yang diperoleh dari jerih payah seseorang dalam bekerja dan dinilai dengan tingkat atau nilai tertentu. Dalam memenuhi kebutuhan, setiap orang pada umumnya akan menyandarkan sumber pembelanjaan dari pendapatan yang diperolehnya dari bekerja (Cobb-Clark et al., 2016; Delafrooz \& Paim, 2011). Pendapatan seseorang merupakan sumber informasi dan stimulus penting dalam melakukan beragam aktivitas, khususnya yang terkait dengan perilaku keuangan. Dengan kata lain pendapatan merubah perilaku keuangan individu (Delafrooz \& Paim, 2011; Ida \& Dwinta, 2010; Perry \& Morris, 2005). Berdasarkan hal tersebut, penelitian ini merumuskan hipotesis :

H3 : Pendapatan berpengaruh positif terhadap perilaku keuangan pengurus Muhammadiyah.

Religiusitas adalah suatu sikap atau kesadaran yang muncul yang didasarkan atas keyakinan atau kepercayaan seseorang terhadap suatu agama (Hess, 2012). Sikap keagamaan merupakan suatu keadaan yang ada pada diri seseorang yang mendorong untuk bertingkah laku sesuai dengan kadar ketaatannya terhadap agama, antara lain keputusan pembelanjaan (Ashraf Ali, 2016). Sebagai pengurus organisasi keagamaan, mereka tentunya memiliki pandangan yang cukup konservatif mengenai ajaran agama. Faktor agama merupakan prasyarat inheren yang melekat di keseharian pengurus organisasi keagamaan, maka perilaku keuangan mereka juga terbentuk dari aspek tersebut. Beberapa penelitian sebelumnya mendukung pendapat tersebut (Ashraf Ali, 2016; Hess, 
2012; Hilary \& Hui, 2009; Kashyap \& lyer, 2009; Renneboog \& Spaenjers, 2012). Berdasarkan hal tersebut, penelitian ini merumuskan hipotesis :

H4 : Religiusitas berpengaruh positif terhadap perilaku keuangan pengurus Muhammadiyah.

\section{METODE PENELITIAN}

Jenis penelitian ini adalah penelitian kuantitatif dengan pendekatan asosiatif kausalitas. Pendekatan tersebut menelaah hubungan kausalitas antara dua variabel atau lebih. Pada penelitian ini, terdapat lima variabel yang diteliti, yaitu locus of control (X1), sikap keuangan (X2), pendapatan (X3), dan religiusitas (x4), yang akan memrediksi variabel perilaku keuangan ( $Y$ ). Penggunaan metode kuantitatif bertujuan untuk mendapatkan gambaran umum mengenai persepsi perilaku keuangan pengurus Muhammadiyah Kabupaten Bantaeng, Sulawesi Selatan.

Penelitian berlokasi di Jalan Raya Lanto No. 57, Komplek Masjid Raya Kantor Pimpinan Daerah Kabupaten Bantaeng, Sulawesi Selatan, pada bulan Juni sampai dengan September 2019. Populasi penelitian mengacu pada jumlah pengurus Muhammadiyah Kabupaten Bantaeng yaitu 60 orang, dan menggunakan teknik sampel jenuh. Sampel jenuh adalah teknik pengambilan sampel bila semua anggota populasi digunakan sebagai sampel. Penelitian ini merupakan penelitian kuantitatif yang mengambil data primer dari responden di lapangan. Penelitian ini menggunakan statistik inferensial untuk menelaah hubungan antar variabel penelitian, dengan teknik regresi linier berganda. Analisis regresi linier berganda digunakan dalam pengolahan data, setelah memastikan kesesuaian data yang digunakan dengan uji asumsi klasik, meliputi uji normalitas, multikolienaritas, dan heteroskedastisitas.

\section{HASIL DAN PEMBAHASAN}

Tahapan pertama yang dilakukan adalah menganalisis validitas dari instrumen penelitian. Hal ini dilakukan dengan membandingkan r-hitung yang merupakan nilai dari corrected item-total correlation dengan r-tabel. Hasil telaah validitas variabel locus of control sebagaimana Tabel 1 berikut. Tabel 1 menunjukkan seluruh instrumen variabel locus of control valid untuk digunakan sebagai instrumen atau pernyataan untuk mengukur variabel yang diteliti, karena r-hitung lebih besar daripada r-tabel.

Tabel 1. Validitas Variabel Locus Of Control $\left(\mathrm{X}_{1}\right)$

\begin{tabular}{|c|c|c|c|c|c|}
\hline No & Instrumen & Item & r-hitung & r-tabel & Keterangan \\
\hline 1. & $\begin{array}{l}\text { Kemampuan memecahkan } \\
\text { masalah pribdi }\end{array}$ & P1 & 0,773 & 0,254 & Valid \\
\hline 2. & Kontrol diri & P2 & 0,577 & 0,254 & Valid \\
\hline 3. & Percaya diri sendiri & P3 & 0,794 & 0,254 & Valid \\
\hline 4. & $\begin{array}{l}\text { Lebih mudah dipengaruhi oleh } \\
\text { lingkungan }\end{array}$ & P4 & 0,735 & 0,254 & Valid \\
\hline 5. & $\begin{array}{l}\text { Tidak berdaya dalam } \\
\text { menghadapi masalah kehidupan }\end{array}$ & P5 & 0,748 & 0,254 & Valid \\
\hline 6. & Memiliki inisiatif & P6 & 0,680 & 0,254 & Valid \\
\hline
\end{tabular}

Sumber : Data diolah. 
Hasil telaah validitas variabel sikap keuangan, sebagaimana Tabel 2 berikut. Tabel 2 menunjukkan seluruh instrumen variabel sikap keuangan valid untuk digunakan sebagai instrumen atau pernyataan untuk mengukur variabel yang diteliti, karena r-hitung lebih besar daripada r-tabel.

Tabel 2. Validitas Variabel Sikap Keuangan $\left(\mathrm{X}_{2}\right)$

\begin{tabular}{clcccc}
\hline No & \multicolumn{1}{c}{ Instrumen } & Item & r-hitung & r-tabel & Keterangan \\
\hline 1. & $\begin{array}{l}\text { Menabung secara rutin dan } \\
\text { teratur }\end{array}$ & P1 & 0,582 & 0,254 & Valid \\
2. & $\begin{array}{l}\text { Melakukan penulisan rencana } \\
\text { (anggaran) }\end{array}$ & P2 & 0,767 & 0,254 & Valid \\
3. & Hemat terhadap uang & P3 & 0,869 & 0,254 & Valid \\
4. & $\begin{array}{l}\text { Bertanggung jawab atas diri } \\
\text { sendiri }\end{array}$ & P4 & 0,769 & 0,254 & Valid \\
\hline
\end{tabular}

Sumber : Data diolah.

Hasil telaah validitas variabel pendapatan, sebagaimana Tabel 3 berikut. Tabel 3 menunjukkan seluruh instrumen variabel pendapatan valid untuk digunakan sebagai instrumen atau pernyataan untuk mengukur variabel yang diteliti, karena r-hitung lebih besar daripada r-tabel.

Tabel 3. Validitas Variabel Pendapatan $\left(\mathrm{X}_{3}\right)$

\begin{tabular}{cccccc}
\hline No & Instrumen & Item & r-hitung & r-tabel & Keterangan \\
\hline \multirow{2}{*}{ 1. } & \multirow{2}{*}{ Pendapatan dari upah dan gaji } & P1 & 0,871 & 0,254 & Valid \\
& P2 & 0,922 & 0,254 & Valid \\
\hline
\end{tabular}

Sumber : Data diolah.

Hasil telaah validitas variabel religiusitas, sebagaimana Tabel 4 berikut. Tabel 4 menunjukkan seluruh instrumen variabel religiusitas valid untuk digunakan sebagai instrumen atau pernyataan untuk mengukur variabel yang diteliti, karena r-hitung lebih besar daripada r-tabel.

Tabel 4. Validitas Variabel Religiosity $\left(\mathrm{X}_{4}\right)$

\begin{tabular}{clcccc}
\hline No & \multicolumn{1}{c}{ Instrumen } & Item & r-hitung & r-tabel & Keterangan \\
\hline 1. & Pengetahuan aqidah dan lima & P1 & 0,841 & 0,254 & Valid \\
& pilar Islam & P2 & 0,747 & 0,254 & Valid \\
2. & Pokok agama & P3 & 0,736 & 0,254 & Valid \\
3. & Perilaku yang terlaksana demi & P4 & 0,884 & 0,254 & Valid \\
& tujuan sosial yang diinginkan & P5 & 0,862 & 0,254 & Valid \\
\hline
\end{tabular}

Sumber : Data diolah.

Hasil telaah validitas variabel perilaku keuangan adalah sebagaimana Tabel 5 berikut. Tabel 5 menunjukkan seluruh instrumen variabel perilaku keuangan valid untuk digunakan sebagai instrumen atau pernyataan untuk mengukur variabel yang diteliti, karena r-hitung lebih besar daripada r-tabel. 
Dampak Locus of Control, Sikap Keuangan, ... Atika Ahman

Tabel 5. Validitas Variabel Perilaku Keuangan (Y)

\begin{tabular}{cccccc}
\hline No & Instrumen & Item & r-hitung & r-tabel & Keterangan \\
\hline 1. & $\begin{array}{c}\text { Membayar tagihan tepat waktu } \\
\text { (misal : listrik, pulsa pasca } \\
\text { bayar, dan lain-lain) }\end{array}$ & P1 & 0,582 & 0,254 & Valid \\
2. & $\begin{array}{c}\text { Mencatat pengeluaran (harian, } \\
\text { bulanan, dan tahunan) }\end{array}$ & P2 & 0,767 & 0,254 & Valid \\
3. & Menyediakan dana terduga \\
$\quad$ (emergency fund) & P3 & 0,869 & 0,254 & Valid \\
4. $\quad \begin{array}{c}\text { Membandingkan harga di } \\
\text { pasar sebelum memutuskan } \\
\text { untuk melakukan pembelian }\end{array}$ & P4 & 0,769 & 0,254 & Valid \\
\hline
\end{tabular}

Sumber : Data diolah.

Suatu kuesioner dikatakan realibel atau handal jika jawaban pertanyaan konsisten dari waktu ke waktu. Ukuran reliabilitas menggunakan ukuran Cronbach's alpha $>0,70$ (Hair, J. F., Hult, G. T. M., Ringle, C. M., \& Sarstedt, 2014; Oviedo Celina \& Campo-Arias, 2005; Panayides, 2013). Adapun hasil uji reliabilitas adalah sebagaimana tabel 6 berikut :

Tabel 6. Reliabilitas Variabel

\begin{tabular}{ccc}
\hline No. & Variabel & Cronbach's Alpha \\
\hline 1. & Locus of Control & 0,813 \\
2. & Sikap Keuangan & 0,784 \\
3. & Pendapatan & 0,748 \\
4. & Religiusitas & 0,869 \\
5. & Perilaku Keuangan & 0,750 \\
\hline
\end{tabular}

Sumber : Data diolah.

Sesuai dengan kriteria uji reliabilitas, maka seluruh nilai alpha memiliki skor di atas 0,7 . Hal ini mengindikasikan bahwa seluruh indikator yang digunakan memenuhi tingkat reliabilitas yang diharapkan. Tahapan berikutnya adalah memastikan seluruh data memenuhi asumsi klasik sebagai salah satu kaidah analisis regresi.

Uji normalitas menggunakan uji Kolmogorov-Smirnov untuk memastikan distribusi data normal atau tidak. Hasil uji normalitas dapat diamati pada Tabel 7 berikut. Pengujian normalitas menunjukkan bahwa data semua variabel berdistribusi normal, dilihat dari nilai signifikan di atas 0,05 yaitu sebesar 0,627.

Tabel 7. Uji Normalitas

\begin{tabular}{llr}
\hline & & Unstandardized Residual \\
\hline $\mathrm{N}$ & & 60 \\
\multicolumn{1}{c}{ Normal Parameters } & a,b Mean &, 0000000 \\
& Std. Deviation & 1,19183907 \\
& Absolute &, 097 \\
Most Extreme Differences & Positive &, 051 \\
& Negative &,- 097 \\
Kolmogorov-Smirnov Z & &, 750 \\
Asymp. Sig. (2-tailed) &, 627 \\
\hline Sumber : Data diolah. &
\end{tabular}


Tahapan berikutnya adalah uji multikolinearitas. Uji multikolinieritas bertujuan menguji apakah pada model regresi ditemukan adanya korelasi antar variabel bebas (Ghozali, 2013). Hasil uji multikolinieritas pada tabel 8 berikut menunjukkan nilai tolerance lebih besar daripada 0,10 dan VIF lebih kecil daripada 10 , sehingga dapat dinyatakan tidak terjadi multikolinieritas pada model penelitian.

Tabel 8 Hasil Uji Multikolinieritas

\begin{tabular}{ccc}
\hline \multirow{2}{*}{ Model } & \multicolumn{2}{c}{ Collinearity Statistics } \\
\cline { 2 - 3 } & Tolerance & VIF \\
\hline X1 &, 711 & 1,407 \\
X2 &, 563 & 1,776 \\
X3 &, 491 & 2,037 \\
X4 &, 795 & 1,257 \\
\hline
\end{tabular}

Sumber : Data diolah.

Hasil pengujian heterokedastisitas menunjukkan bahwa tidak ada satupun variabel independen yang signifikan mempengaruhi variabel dependen nilai Absolut Ut (AbsUt). Hal ini terlihat dari probabilitas signifikansinya di atas tingkat kepercayaan 5 persen. Jadi dapat dinyatatakan model regresi tidak mengandung heterokedastisitas. Hasil uji heterokedastisitas dapat dilihat pada Tabel 9.

Tabel 9 Hasil Uji Heterokedastistas

\begin{tabular}{|c|c|c|c|c|c|}
\hline \multirow[t]{2}{*}{ Model } & \multicolumn{2}{|c|}{$\begin{array}{l}\text { Unstandardized } \\
\text { Coefficients }\end{array}$} & \multirow{2}{*}{$\begin{array}{c}\begin{array}{c}\text { Standardized } \\
\text { Coefficients }\end{array} \\
\text { Beta }\end{array}$} & \multirow[t]{2}{*}{$t$} & \multirow[t]{2}{*}{ Sig. } \\
\hline & B & Std. Error & & & \\
\hline (Constant) & 2,274 & 1,034 & & 2,199 &, 032 \\
\hline $\mathrm{X} 1$ &,- 023 & ,033 &,- 109 &,- 706 & ,483 \\
\hline$X 2$ &,- 068 & ,071 &,- 167 &,- 962 & ,340 \\
\hline X3 &,- 034 & , 106 &,- 059 &,- 319 & ,751 \\
\hline X4 & ,048 & ,035 & 197 & 1,348 & 183 \\
\hline
\end{tabular}

Sumber : Data diolah.

Adapun hasil analisis regresi linier berganda adalah sebagaimana Tabel 10 berikut :

Tabel 10. Analysis of Variance

\begin{tabular}{lcrrrc}
\hline \multicolumn{1}{c}{ Variabel } & $\mathbf{R}^{\mathbf{2}}$ & F-value & $\mathbf{t}$-value & $\mathbf{p}$-value & Hipotesis \\
\hline Locus of control & & & 2,060 & 0,044 & Diterima \\
Sikap keuangan & & & 2,019 & 0,048 & Diterima \\
Pendapatan & \multirow{2}{*}{1.564} & 17.916 & 2,225 & 0,030 & Diterima \\
Religiusitas & & & 2,401 & 0,020 & Diterima \\
\hline
\end{tabular}

Sumber : Data diolah.

Berasarkan tabel diatas nilai $R$ square adalah sebesar 0,564 atau 56,4 persen yang berarti variabel perilaku keuangan pengurus Muhammadiayah Kabupaten Bantaeng dapat dijelaskan variabel locus of control, sikap keuangan, pendapatan dan religiusitas, sedangkan sisanya sebesar 43,6 persen dijelaskan oleh faktor-faktor yang lain di luar model. Nilai fhitung sebesar 17,916 dengan tingkat signifikan 0,000 . Oleh sebab itu, dapat dinyatakan bahwa locus of control, sikap keuangan, pendapatan, dan religiusitas secara simultan 
berpengaruh signifikan terhadap perilaku keuangan pengurus Muhammadiyah Kabupaten Bantaeng.

Adapun persamaan regresi linier berganda yang diperoleh dari penelitian adalah sebagai berikut :

$$
Y=4,753+0,110 X_{1}+0,253 X_{2}+0,387 X_{3}+0,140 X_{4}
$$

Nilai koefisien regresi locus of control sebesar 0,110 berarti bahwa jika terjadi peningkatan locus of control maka perilaku keuangan pengurus Muhammadiyah Kabupaten Bantaeng juga akan meningkat. Penelitian yang membahas hubungan antara dua konstruk tersebut sangat sedikit. Salah satu di antaranya menemukan bahwa siswa yang memiliki locus of control eksternal yang kuat memiliki perilaku keuangan yang lebih buruk, dibandingkan siswa yang kuat sisi internalnya (Britt et al., 2013). Studi dengan data dari Indonesia juga mengonfirmasi hubungan ini (Ida \& Dwinta, 2010). Faktor locus of control juga memiliki dampak baik bagi hasil kinerja keuangan tim proyek, bila faktor internal yang mendominasi, dan bukan eksternal (Boone, Van Olffen, \& Van Witteloostuijn, 2005).

Nilai koefisien regresi sikap keuangan sebesar 0,253 berarti bahwa jika terjadi peningkatan sikap keuangan maka perilaku keuangan pengurus Muhammadiyah Kabupaten Bantaeng juga akan meningkat. Sikap keuangan seseorang dapat membantu individu tersebut dalam menentukan sikap dan perilaku mereka dalam hal pengelolaan keuangan, penganggaran keuangan pribadi, atau keputusan mengenai bentuk investasi. Dengan kata lain sikap keuangan seseorang adalah bagaimana seseorang memiliki pandangan mengenai uang yakni uang sebagai sumber kekuatan dan kebebasan, prestasi, ataupun sumber kejahatan (Sohn, Joo, Grable, Lee, \& Kim, 2012). Oleh sebab itu sikap keuangan sangat berperan penting dalam menentukan perilaku keuangan seseorang (Yap et al., 2018). Sebuah studi pada sejumlah suku yang berbeda menyimpulkan bahwa kecerdasan dalam mengelola faktor moneter pribadi akan berdampak baik pada perilaku keuangan (Tang et al., 2018).

Nilai koefisien regresi pendapatan sebesar 0,387 berarti bahwa jika terjadi peningkatan pendapatan maka perilaku keuangannya juga akan meningkat. Keinginan pengurus Muhammadyah yang ingin membelanjakan pendapatan yang diterima tanpa mengontrol keuangan dapat menyebabkan kegagalan dalam mengelola keuangan. Pendapatan merupakan salah satu faktor demografi yang penting dalam menjelaskan perilaku keuangan individu, selain pengetahuan keuangan dan status perkawinan (Delafrooz \& Paim, 2011). Ini membuktikan peran pendapatan dalam membentuk perilaku individu (Perry \& Morris, 2005).

Nilai koefisien regresi religiusitas sebesar 0,140 berarti bahwa jika terjadi peningkatan religiusitas maka perilaku keuangan pengurus Muhammadiyah Kabupaten Bantaeng juga akan meningkat. Semakin tinggi religiustitas yang dimilki oleh pengurus Muhammadiyah Kabupaten Bantaeng akan mendorong semakin baik pula pengelolaan keuangannya. Religiusitas menandakan seberapa sering individu menjalankan syariat agama yang telah dianutnya. Hal ini berarti pengurus Muhammadiyah yang tekun menjalankan perintah Islam dan menghindari larangan dalam Islam, maka semakin religius, dan sebaliknya. Temuan ini mendukung studi yang mengemukakan peran faktor agama dalam membentuk perilaku konsumen (Ashraf Ali, 2016). Dampak faktor agama bahkan terasa pada negara bagian Amerika Serikat yang menunjukkan eksposur risiko yang lebih rendah, dan menunjukkan 
bagaimana peran agama dalam menahan laju tindakan mencari risiko pemeluk-pemeluknya (Hilary \& Hui, 2009). Faktor-faktor tersebut menjadi pembeda atas beragam keputusan investasi individu (Kashyap \& lyer, 2009). Pada level rumah tangga, hipotesis peran agama terhadap sikap keuangan pemeluknya juga terbukti signifikan (Renneboog \& Spaenjers, 2012). Keseluruhan studi ini mendukung teori bahwa peran agama membentuk sikap keuangan pemeluknya (Hess, 2012).

Temuan penelitian ini mengisyaratkan bahwa locus of control, sikap keuangan, pendapatan, dan religiusitas merupakan faktor penting yang menentukan baik tidaknya perilaku keuangan pengurus Muhammadiyah Kabupaten Bantaeng. Semakin tinggi locus of control, sikap keuangan, pendapatan, dan religiusitas, akan mendorong semakin baiknya perilaku keuangan pengurus Muhammadiyah Kabupaten Bantaeng. Sebaliknya jika locus of control, sikap keuangan, pendapatan, dan religiusitas rendah, maka perilaku keuangan pengurus Muhammadiyah Kabupaten Bantaeng juga akan mengalami penurunan.

Penelitian ini mendukung penelitian sebelumnya yang mengemukakan bahwa terdapat tiga faktor yang mempengaruhi perilaku keuangan seseorang yaitu persepsi diri individu terhadap apapun yang terjadi dalam kehidupannya atau locus of control, pendapatan, dan pengetahuan mereka (Perry \& Morris, 2005). Faktor religiusitas juga mempengaruhi perilaku keuangan pribadi ketika melakukan berbagai keputusan keuangan (Hess, 2012).

\section{KESIMPULAN}

Berdasarkan analisis hasil penelitian serta pembahasan, maka dapat ditarik kesimpulan bahwa locus of control, sikap keuangan, pendapatan, dan religiusitas baik secara parsial maupun simultan berpengaruh secara signifikan terhadap perilaku keuangan pengurus Muhammadiyah Kabupaten Bantaeng, Sulawesi Selatan. Variabel yang paling dominan pengaruhnya terhadap perilaku keuangan adalah pendapatan. Dengan demikian, semakin meningkat pendapatan individu akan memicu peningkatan perilaku keuangan pengurus Muhammadiyah Kabupaten Bantaeng, Sulawesi Selatan.

\section{DAFTAR PUSTAKA}

Amar, M. Y., Syariati, A., \& Rahim, F. R. (2019). Enhancing Hotel Industry Performance Through Service Based Resources and Strategic Enterpreneurship (Case Study At Hotel Industries In Indonesia). Academy of Entrepreneurship Journal, 25(3), 1-10.

Ameliawati, M., \& Setiyani, R. (2018). The Influence of Financial Attitude, Financial Socialization, and Financial Experience to Financial Management Behavior with Financial Literacy as the Mediation Variable. KnE Social Sciences. International Conference on Economics, Business and Education 2018, 811-832.

Ashraf Ali, K. (2016). Impact of Religiosity on Buying Behavior of Financial Products: A Literature Review. International Journal of Finance and Banking Research, 2(1), 1823. 
Boone, C., Van Olffen, W., \& Van Witteloostuijn, A. (2005). Team Locus-of-Control Composition, Leadership Structure, Information Acquisition, and Financial Performance: A Business Simulation Study. Academy of Management Journal, 48(5).

Britt, S., Cumbie, J. a., \& Bell, M. M. (2013). The Influence of Locus of Control on Student Financial Behavior. College Student Journal.

Delafrooz, N., \& Paim, L. (2011). Personal Saving Behavior among Malaysian Employees: Socio Demographic Comparison. International Conference on Social and Humanity.

Enrico, A., Aron, R., \& Oktavia, W. (2013). The Factors that Influenced Consumptive Behavior: A Survey of University Students in Jakarta. SSRN Electronic Journal.

Falahati, L. (2011). A comparative study in Money Attitude among University Students: A Gendered View. Journal of American Science.

Ghozali, I. (2013). Aplikasi Analisis Multivariate dengan Program IBM dan SPSS 21. In Aplikasi Analisis Multivariate dengan Program IBM SPSS 21. Semarang : Penerbit Universitas Diponegoro.

Hair, J. F., Hult, G. T. M., Ringle, C. M., \& Sarstedt, M. (2014). Partial Least Squares Structural Equation Modeling (PLS-SEM). Sage Publisher. European Business Review, 26(2), 106-121.

Hess, D. (2012). The Impact of Religiosity on Personal Financial Decisions, 14, 1-13.

Hilary, G., \& Hui, K. W. (2009). Does Religion Matter in Corporate Decision Making in America? Journal of Financial Economics, 93(3), 455-473.

Ida, \& Dwinta, C. Y. (2010). Pengaruh Locus of Control, Financial Knowledge, Income Terhadap Financial Management Behavior. Jurnal Bisnis Dan Akuntansi.

Kashyap, R., \& lyer, E. S. (2009). Not Everybody Wants to Save the World. Journal of Financial Services Marketing, 14, 118-134.

Lai, C. W. (2010). How Financial Attitudes and Practices Influence the Impulsive Buying Behavior of College and University Students. Social Behavior and Personality : an International Journal, 38(3), 373-380.

Meghir, C., \& Pistaferri, L. (2011). Earnings, Consumption and Life Cycle Choices. In Handbook of Labor Economics, 4, 773-854.

Nofsinger, J. R. (2001). The Impact of Public Information on Investors. Journal of Banking and Finance, 25(7), 1339-1366.

Oviedo Celina, H., \& Campo-Arias, A. (2005). An Approach to the Use of Cronbach's Alfa. Revista Colombiana de Psquiatría.

Panayides, P. (2013). Coefficient Alpha: Interpret with Caution. Europe's Journal of Psychology, 9(4).

Parmitasari, R. D. A., Alwi, Z., \& S., S. (2018). Pengaruh Kecerdasan Spritual dan Gaya Hidup Hedonisme terhadap Manajemen Keuangan Pribadi Mahasiswa Perguruan Tinggi Negeri di Kota Makassar. Jurnal Minds: Manajemen Ide Dan Inspirasi, 5(2), 147-162.

Perry, V. G., \& Morris, M. D. (2005). Who is in Control? The Role of Self-Perception, Knowledge, and Income in Explaining Consumer Financial Behavior. Journal of Consumer Affairs, 39(2), 299-313.

Renneboog, L., \& Spaenjers, C. (2012). Religion and Finance. In Socially Responsible Finance and Investing : Financial Institutions, Corporations, Investors, and Activists. Chapter 8. John Wiley and Sons, Inc. 
Ricciardi, V. (2008). The Psychology of Risk: The Behavioral Finance Perspective. In Handbook of Finance. John Wiley and Sons, Inc.

Robbins, S., \& Judge, T. (2009). Organizational Behaviour: Concepts, Controversies, Applications. In Development.

Rotter, J. B. (1966). Generalized Expectancies for Internal Versus External Control of Reinforcement. Psychological Monographs, 80(1), 1-28.

Shefrin, H., \& Statman, M. (2000). Behavioral Portfolio Theory. The Journal of Financial and Quantitative Analysis, 35(2), 127-151.

Sitepu, N. I. (2017). Perilaku Konsumsi Islam Di Indonesia. Jurnal Perspektif Ekonomi Darussalam. 2(1), 91-106.

Sohn, S. H., Joo, S. H., Grable, J. E., Lee, S., \& Kim, M. (2012). Adolescents' Financial Literacy: The Role of Financial Socialization Agents, Financial Experiences, and Money Attitudes in Shaping Financial Literacy Among South Korean Youth. Journal of Adolescence, 35(4), 969-980.

Spector, P. E. (1988). Development of the Work Locus of Control Scale. Journal of Occupational Psychology, 61(4), 335-340.

Suhartini, E., \& Anisa, N. (2017). Pengaruh Kecerdasan Emosional dan Kecerdasan Spiritual terhadap Kinerja Perawat Rumah Sakit Daerah Labuang Baji Makassar. Jurnal Minds: Manajemen Ide Dan Inspirasi, 4(1), 16-29.

Tang, T. L. P., Sutarso, T., Ansari, M. A., Lim, V. K. G., Teo, T. S. H., Arias-Galicia, F., Tang, N. (2018). Monetary Intelligence and Behavioral Economics Across 32 Cultures: Good Apples Enjoy Good Quality of Life in Good Barrels. Journal of Business Ethics, 148, 893-917.

Wallston, K. A., Wallston, B. S., \& DeVellis, R. (1978). Development of the Multidimensional Health Locus of Control (MHLC) Scales. Health Education \& Behavior, 6(1).

Xiao, J. J. (2008). Applying Behavior Theories to Financial Behavior. In Handbook of Consumer Finance Research. Springer, New York.

Yap, R. J. C., Komalasari, F., \& Hadiansah, I. (2018). The Effect of Financial Literacy and Attitude on Financial Management Behavior and Satisfaction. Bisnis \& Birokrasi Journal, 23(3), 140-146. 